
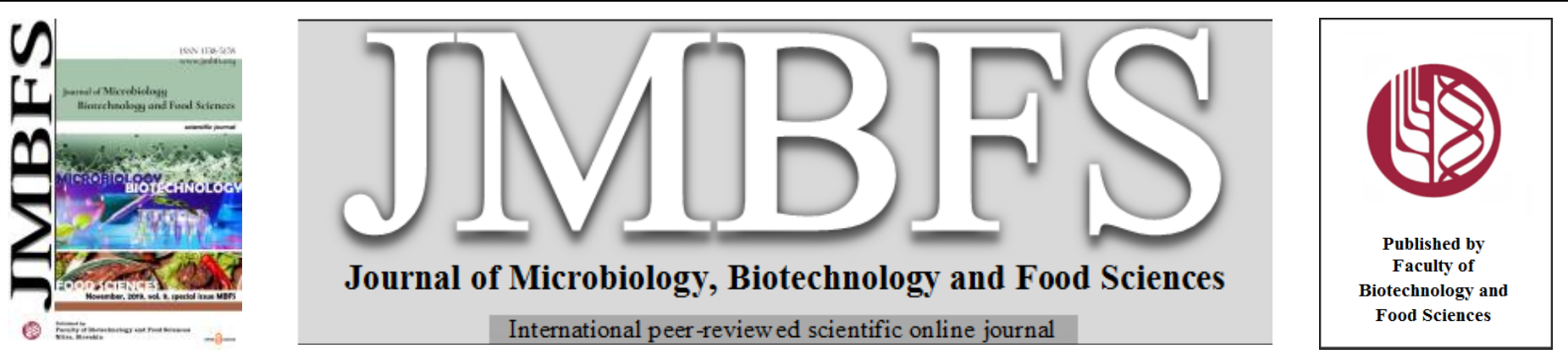

\title{
MICROBIOLOGY SAFETY ASSESSMENT OF BRINE AFTER WET SALTING OF MEAT
}

\author{
Miroslav Kročko ${ }^{1 *}$, Viera Duckovál, Ondřej Bučko², Marek Bobko ${ }^{1}$, Jana Tkáčovál
}

\section{Address(es):}

${ }^{1}$ Slovak University of Agriculture in Nitra, Faculty of Biotechnology and Food Sciences, Department of Technology and Quality Animal Products, Tr. A. Hlinku 2, 949 76 Nitra, Slovakia.

${ }^{2}$ Slovak University of Agriculture, Faculty of Agrobiology and food resources, Department of Animal Husbandry, 94976 Nitra, Nitra, Tr. A. Hlinku 2, Slovakia.

*Corresponding author: mirokrocko@yahoo.com

doi: 10.15414/jmbfs.2019.9.special.431-433

\section{ARTICLE INFO}

Received 30. 7. 2019

Revised 15. 10. 2019

Accepted 16. 10. 2019

Published 8. 11. 2019

\section{Regular article}

OPEN $\bigodot_{\text {ACCESS }}$

\begin{abstract}
The aim of the study was to determine the microbial safety of brine and the effect of bacterial starter culture containing CNS strains of Staphylococcus carnosus and Staphylococcus xylosus (Indasia, Germany) on the microbiological quality of the brine during wet salting of the meat. In the first experiment was determined the microbial safety of brine with different concentrations of curing salt and with addition of bay leaf, whole black pepper; whole juniper and whole new pepper water extracts. In the second experiment were prepared brine samples with $9.5 \%$ of curing salt, brine samples with the same concentration of curing salt but with the addition of a starter culture and brines with the concentration $7.5 \%$ of curing salt, starter culture and spices water extracts same as in previous experiment. The commercial starter culture contains strains of Staphylococcus carnosus and Staphylococcus xylosus (CNS) was added in amount of 0.2g. Safety assessment of the brine was established according to results of $\mathrm{pH}$ value, salinity, color and count of coliform bacteria, psychrotrophic bacteria, Lactobacillus sp. and Streptococcus sp. The results show that the very presence of $9.5 \%$ salt and nitrite does not prevent the decline of microorganisms in brine samples used for salting meat. Protective culture helped reduce the number of unwanted microorganisms and promoted lactobacilli. However, the demonstrably higher antibacterial effect of the protective culture, determined on the basis of the number of psychotropic microorganisms, was found to be combined with the spice extract.
\end{abstract}

Keywords: brine, wet salting, bacteria, CNS, color

\section{INTRODUCTION}

Salting is one of the oldest processes of meat preservation. Sodium chloride solution was commonly used to treat meat pieces or the meat was covered with a dry salt layer. The salt itself caused a decrease of the water activity value in the meat, thus preventing microbial damage and unwanted organoleptic changes. The ancient Sumerians consider themselves the first civilization to use meat and fish preserving salt around 3000 BC. Dead Sea salt was first used in ancient Palestine as early as 1600 BC. Chinese and Greeks also used stone salt, which was later used by ancient Romans (Pereira and Vicente, 2013; Wojnowski et al., 2017). Salting methods can be divided into two basic categories: dry and wet (saline, brine). Dry salting is the oldest traditional technique in which salt with nitrites or even nitrates is applied to the surface of the meat. In brine salting processes, the individual components are dissolved in water to form brine, in which the meat is naturally located for a period of time or injected directly into the meat (Shahidi and Samaranayka, 2004). These two salting methods can also be combined with each other. Combined method has obtained popularity in the fish industry. The method that is generally used is as follows: the fish is immersed for 1-4 days in a solution of salt, with salt concentration is $17 \% \mathrm{NaCl}$; removal from the brine; the fillets are placed with thin layers of salt, into stacks or in plastic tubs; the fish is then kept stacked for 10-14 days for dry salting after which it is packed (Aberoumand and Nejad, 2015).

Wet curing (saline, brine) has been applied to a wide range of food, such as vegetables, cheese, fish, and meat products. The curing of meat is important, as meat is a valuable source of protein which decomposes rapidly when not preserved (Pereira and Vicente, 2013; Wojnowski et al., 2017). The rate of diffusion of salt and functional ingredients into the feedstock depends on the salt concentration, the size of the individual pieces of raw material, tumbling process and on the content of fibrous and fat portions that act as a diffusion barrier (blending for protein activation) (Feiner et al., 2006). The antimicrobial activity of $\mathrm{NaCl}$ is reviewed in light of currrent calls for a reduction of $\mathrm{Na}+$ in the human diet due to health reasons, and the possible replacement of $\mathrm{NaCl}$ in processed foods with chloride salts of other ions (i.e. $\mathrm{KCl}, \mathrm{MgCl} 2, \mathrm{CaCl} 2$ ) (Sofos, 1984).
Over time, it has been found that only some types of salt have helped to develop the desired color and characteristic taste of the meat. The nineteenth-century investigation revealed that sodium nitrate, present as an impurity in these salts, is responsible for the development of the characteristic color and taste of salted meat. Later it was found that the desired effect occurs through microbial reduction of nitrates to nitrites. From the subsequent experiments, regulations were introduced for the direct addition of sodium nitrite in order to prolong the shelf life of the meat while maintaining the color and desired flavor. Current practice includes the addition of sodium nitrite, ascorbates or erythorbates, additives such as e.g. sweeteners, phosphates, spices and smoke flavor (Skovgaard, 1992).

The production of fermented meat products is based primarily on the metabolic activities of lactic acid bacteria and subsequently catalysis of positive cocci, in particular the coagulase-negative staphylococci (CNS). On the other hand, in the production of salted meat, the CNS has been monitored primarily for a long time. Their use usually leads to the appropriate formation of meat color based on their nitrate reductase activity, while their catalase activity reduces oxidative damage. In addition, CNS metabolism contributes to taste, although the exact effects are difficult to estimate. There are reasons to believe that these basic technological features of the CNS can be further enhanced by examining their overall metabolic potential. Rational selection of CNS strains can lead to the development of new cultures with enhanced functionality. Their ability to contribute to the formation of meat color could be optimized to reduce the amount of saline needed, either by selecting effective nitrate reducing CNS strains or by exploring a potential alternative based on nitric oxide synthase activity. Finally, bacteriocin-producing CNS strains may offer solutions for bioprotection against meat pathogens such as Clostridium botulinum and Staphylococcus aureus (Sanchez Mainar et al., 2017).

The aim of the study was to determine the microbial safety of brine with different amount of salt and spices extract and the effect of bacterial starter culture containing CNS strains of Staphylococcus carnosus and Staphylococcus xylosus (Indasia, Germany) on the microbiological quality of the brine during wet salting of the meat. 


\section{MATERIAL AND METHODS}

\section{Brines models preparation and experimental set-up}

\section{First experiment}

It is well known that the concentration of salt as well as nitrites in the wet salting process in the brine gradually decreases; thereby the antibacterial effect of this brine is reduced. For this reason, the first experiment was established to determine the microbial safety of brine with different concentrations of curing salt additions

Samples of brines were prepared according to traditional procedures used in a small and large fully functional curing facilities located in the Slovak republic Pork samples (musculus longissimus dorsi) were cut to a weight of $100 \mathrm{~g}$. The ratio of raw material and brine set to 1: 3. Preparation of $300 \mathrm{ml}$ samples of the brine consisted of a $9.5 \% ; 8.5 \% ; 7.5 \%$; and $6.5 \%$ curing salt $(\mathrm{NaCl} 99.5 \%$ and $\mathrm{NaNO}_{2} 0.5 \%$ ) addition. For last experimental sample of brine, was first added to $500 \mathrm{ml}$ of water; $0.5 \mathrm{~g}$ of bay leaf, $0.5 \mathrm{~g}$ whole black pepper; $0.5 \mathrm{~g}$ of whole juniper and $0.5 \mathrm{~g}$ of whole new pepper. In a sealed vessel, the solution was brought to boiling for 10 minutes (this time was sufficient to reduce the volume from $500 \mathrm{ml}$ to $300 \mathrm{ml}$.) and, after cooling the spices were removed. The curing salt $(7.5 \%)$ was added to $300 \mathrm{ml}$ of this solution. Meat samples were stored at $4 \pm$ $1{ }^{\circ} \mathrm{C}$ for 10 days after loading in saline.

\section{Second experiment}

In the second part of the experiment, were prepared brine samples with $9.5 \%$ of curing salt $\left(\mathrm{NaCl} 99.5 \%\right.$ and $\mathrm{NaNO}_{2}$ 0.5\%) (K), brine samples with the same concentration of curing salt but with the addition of a starter culture (P1). Only brines of $\mathrm{P} 2$ were prepared with the concentration $7.5 \%$ of curing salt and spices water extracts same as in previous experiment. Starter culture was also added to these samples in amount of $0.2 \mathrm{~g}$. The commercial starter culture contains strains of Staphylococcus carnosus and Staphylococcus xylosus (Indasia, Germany) in the amount of $\log 11 \mathrm{KTJ} . \mathrm{g}^{-1}$. Samples of meat were not investigated in this study.

\section{pH and salinity measurement}

After sampling, the $\mathrm{pH}$ was measured directly in the brine with a Gryf 209L pH meter (Gryf, Czech Republic) equipped with an insertion $\mathrm{pH}$ probe. Salinities of each brine solutions were measured using a refractometer.

\section{Color measurement}

Color spaces of $\mathrm{L}^{*}, \mathrm{a}^{*}, \mathrm{~b}^{*}$ were determined by CM 2600D spectrophotomete (Konica Minolta, Germany). Color of brine in second experiment was measured with SCE (Specular Component Excluded).

\section{Enumeration of microorganisms}

One mililiter of brine were aseptically transferred into a glass tubes and appropriate decimal dilutions in saline were prepared and spread on selective agar.

The determination of coliform bacteria was carried out on VRB agar (after cultivation for 24 hours at $30^{\circ} \mathrm{C} \pm 1^{\circ} \mathrm{C}$ (ISO 4832).

The total number of psychrotorphic microorganisms (TPM) was determined on the PCA agar (HiMedia, India) after 10 days of culture at $4 \pm 1^{\circ} \mathrm{C}$.

Lactobacillus bacteria were assayed on MRS agar by culture at $30^{\circ} \mathrm{C} \pm 1{ }^{\circ} \mathrm{C}$. After 5 days of culture, their numbers were read (ISO 15214, 2002).

The total number of streptococci was determined on the M17 agar (HiMedia, India) by incubation at $30 \pm 1^{\circ} \mathrm{C}$ for 3 days (ISO 15214).

\section{RESULTS AND DISCUSSION}

Regarding $\mathrm{pH}$, statistically differences among the samples were observed. Value of $\mathrm{pH}$ was compare to other brines significantly higher in $6.5 \%$ brine and the lowest in $9.5 \%$ brine after 10 days of salting. Statistically no differences were observed among the samples of $7.5 \% ; 8.5$ and $7.5+$ spices brines. The $\mathrm{pH}$ value of brine can be used as an indicator of degree of freshness or spoilage of salted meat. In fresh meat $\mathrm{pH}$ is close to neutral, first it decreases due to lactic acid arising from death, however then it increases because of deterioration. The reason for this increase is the disruption to the oxidation-reduction balance along with the effect of enzymes and bacteria, and the changes in the concentration of free hydrogen and hydroxyl ions (Varlık et al., 1993). The increase in $\mathrm{pH}$ indicates the loss of quality (Latifa et al., 2014).

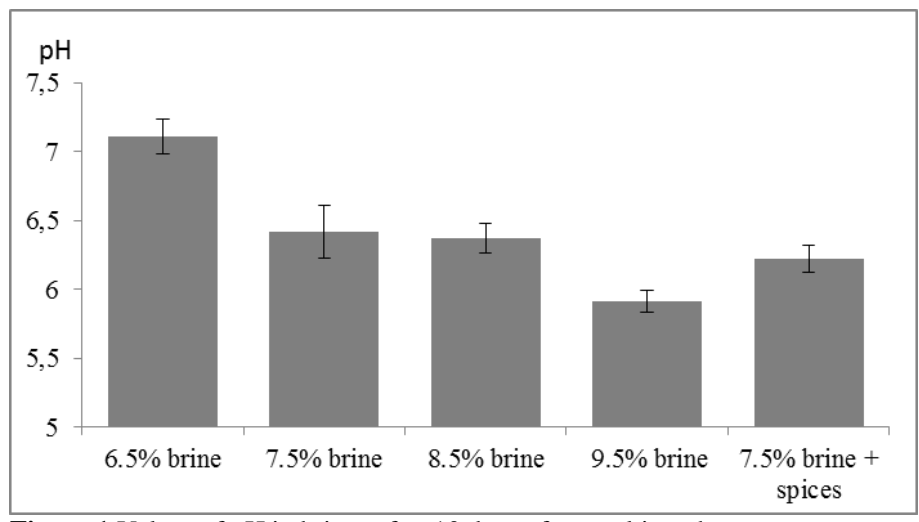

Figure 1 Values of $\mathrm{pH}$ in brines after 10 days of wet salting phase

The process of salting and subsequent drying of meat is the most common way of treating meat to obtain a safe product intended also for direct consumption by consumers. Therefore, it is important to ensure sufficient bactericidal effect of brine, especially against coliform bacteria and streptococci (Cardoso-Toset et al., 2017).

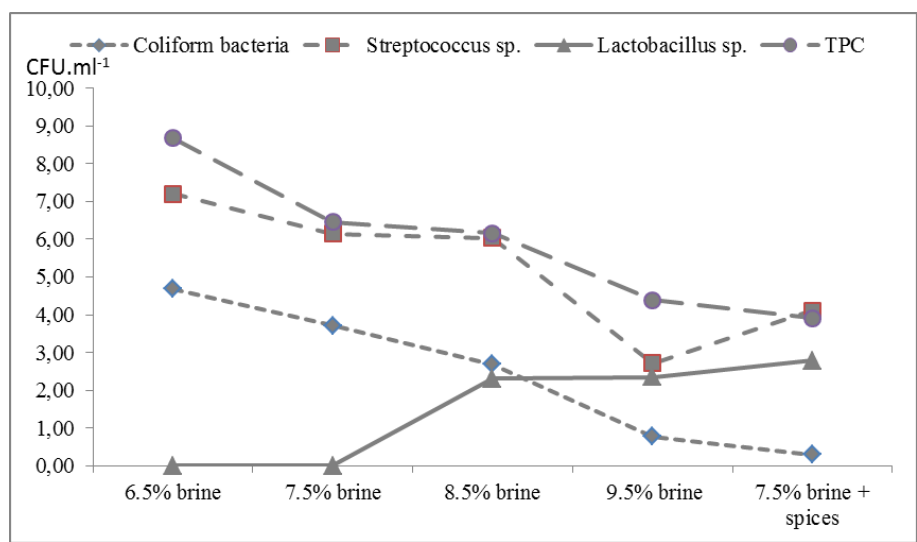

Figure 2 Number of microorganisms in brines after 10 days of wet salting phase

The number of coliform bacteria, Streptococcus sp. and TPC bacteria was found to be highest in all of brine with concentration of curing salt $6.5 \%$. These findings are in accordance with study of Durack et al. (2013) who reported that salt within brine was introduced to reduce the rate of deterioration of meat by reducing the growth of microorganisms. High concentration of salt in brine results in greatly reduced loads of Psychrotrophic bacteria in brine and inhibits microbial spoilage of meat.

The amount of Lactobacillus bacteria were not detected in brine solutions of 6.5 and $7.5 \%$. This group of microorganisms was probably suppressed by other species of microorganisms as they occurred in brines with higher salt concentrations.

The total number of coliform microorganisms in the saline samples at the end of the wet salting time ranged from 0.3 to $4.68 \log \mathrm{CFU} / \mathrm{ml}$. The lowest numbers of coliform microorganisms were recorded in samples with addition of spices extract and with a reduced salt concentration of $7.5 \%$.

The results show that curing salt is effective against undesirable microorganisms in the wet salting process only if its concentration is maintained at $9.5 \%$ or more throughout the salting time. This also ensures a sufficient amount of nitrites that act as antimicrobials.

Nitrate itself has little antimicrobial effect and in most applications could be replaced by lower concentrations of nitrite. Further, improved hygiene diminishes the need for nitrite. The antimicrobial activity and technological needs for nitrate and nitrite are reviewed. It is concluded that the technological needs for nitrite in meat products stored at $<10^{\circ} \mathrm{C}$ could be met by added nitrite concentrations of $50 \mathrm{mg} / \mathrm{kg}$. In such products, Vibrio parahaemolyticus does not grow at salt concentrations of $10 \%$ and food poisoning by this organism is not related to the absence of nitrate or nitrite; growth of Clostridium botulinum Type E (the predominant cause of botulism from fish products) is arrested by salt concentrations of 3-4\%. Listeria monocytogenes in seafood cannot be controlled by nitrite (Skovgaard, 1992). 


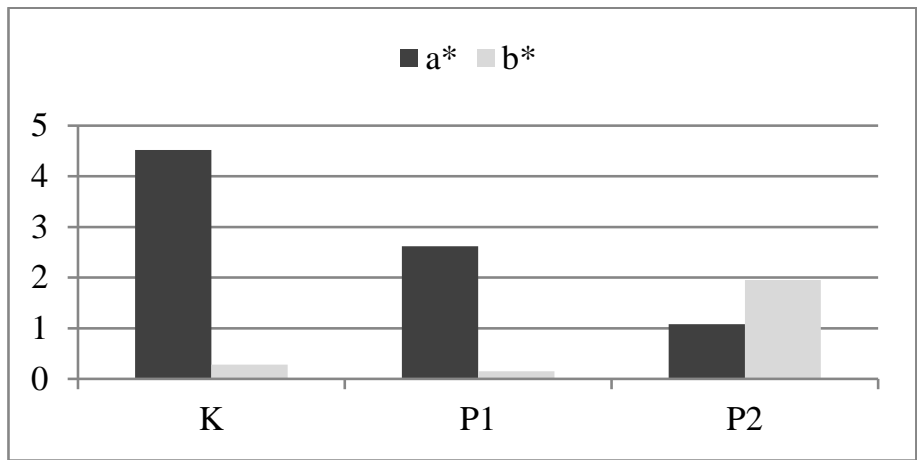

Figure 3 Intensity of redness $\left(a^{*}\right)$ and yellowness $\left(b^{*}\right)$ of brine after 10 day of salting period

Microbiologically unstable meat brines are characterized by a color change. Microbiologically degraded solutions may have a reddish or dark brown color and unpleasant smell. Intensity of brine lightness after 10 days of meat salting period was highest in samples of P2 (26.52), followed samples of P1 (25.57) and $\mathrm{K}$ (25.51). Intensity of red color ( $\left.\mathrm{a}^{*}\right)$ during the whole period of salting was significantly highest in brine samples of control group.

The higher yellowness and discoloration in the meat products might be related to a higher lipid oxidation caused by the microbial lipases produced by the starter cultures. The lipid oxidation in meat products can reduce myoglobin stability, making it more susceptible to oxidation, which decreases the red color an increases the discoloration of red meat (Kennedy et al., 2004). The increased intensity of yellow color in brine samples of $\mathrm{P} 2$ group is probably caused due to the addition of spices extract.

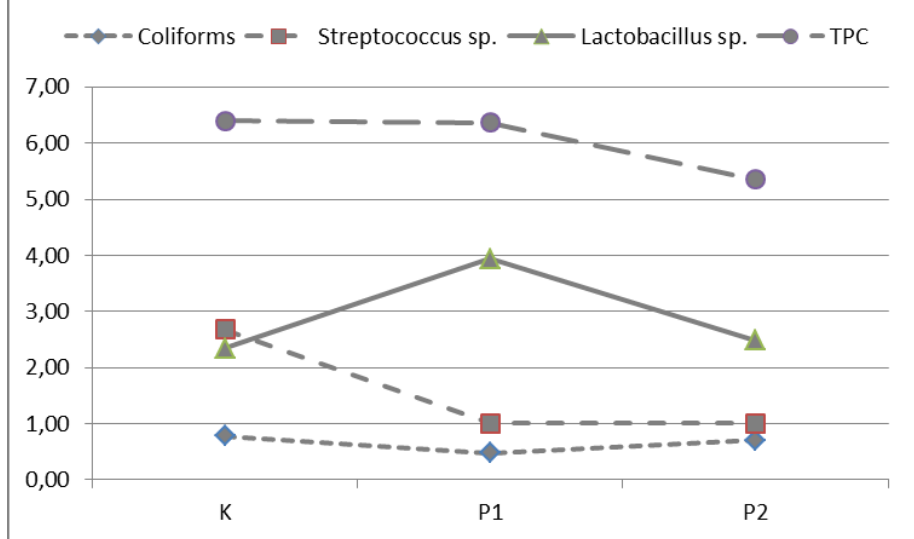

Figure 4 Number of microorganisms in brines with starter cultures after 10 days of wet salting phase

In the second experiment were among count of coliform bacteria in brine samples not detected significant differences and their count were below $1 \log$ CFU/ml in all tested brine samples (figure 3). The total number of streptococci in brine samples ranged from 1.0 to $2.65 \log \mathrm{CFU} / \mathrm{ml}$. The lowest numbers of this group of microorganisms were recorded in both samples with the addition of protective culture and also with protective culture and spices.

In the brine samples prepared with the spice extract and also bacterial culture, the number of psychrotrophic microorganisms was found to be significantly lower by $1.1 \log \mathrm{CFU} / \mathrm{ml}$ than that of the other brine samples. In addition to taste, spices can also provide antiseptic and preservative properties due to the presence of essential oils. Antimicrobial activity depends on the type of spices, the type of food to which it is added, the composition and content of the extracts. Thus, in addition to providing strong flavors, they have antioxidant properties that inhibit lipid oxidation. The antioxidant properties of spices are caused by the presence of flavonoids, terpenoids, lignans or polyphenols. Thanks to these properties, they can help maintain the stability of the saline solution (Cassens, 2008). Growth of psychrotrophic bacteria in the control group may be related to an increase of the accompanying microflora characteristic for brine and meat, but may also be associated with the development of CNS strains that have been directly added to the brine samples of P1 and P2. Our findings are consistent with the findings of Binici and Kaya (2017), who also noted an increase in the number of psychotrophic microorganisms during 15 days of wet fish salting to $8 \log \mathrm{CFU} / \mathrm{g}$.

\section{CONCLUSION}

The results indicate that the presence of $10 \%$ salt and nitrites alone will not reduce the microorganisms in saline solutions used for salting meat. Starter culture helped to reduce the number of undesirable microorganisms and promoted lactobacilli growth. However, a significantly higher antibacterial effect based on the number of psychotrophic microorganisms was found to be combined with the extract from the spices.

Acknowledgments: This work has been supported by a grant of KEGA 025SPU4/2019.

\section{REFERENCES}

ABEROUMANDAND, A., NEJAD, S. Z. 2015. Effects of brining process on nutrient composition of fish species (kharo, govazim and kijar) from Iran International Journal of Agricultural Research, Innovation and Technology 5, 36-39, https://doi.org/10.3329/ijarit.v5i1.24585

BINICI, A., KAYA, G. K.. 2017. Effect of brine and dry salting methods on the physicochemical and microbial quality of chub (Squalius cephalus Linnaeus, 1758). Food Science and Technology 38, 66-70. http://dx.doi.org/10.1590/1678 457x.15717.

CARDOSO-TOSET, F., LUQUE, I., MORELES-PARTERA, A. et al. 2017 Survival of Streptococcus suis, Streptococcus dysgalactiae and Trueperella pyogenes in dry-cured Iberian pork shoulders and loins. Food Microbiology 61, 66-71. https://doi.org/10.1016/j.fm.2016.09.002

CASSENS, R. G. 2008. Meat preservation:Preventing Losses and Assuring Safety. Hoboken : John Wiley \& Sons : 133 p. ISBN 0-917678-34-6. https://doi.org/10.1002/9780470385029

DURACK, E., ALONSO-GOMEZ, M., WILKINSON, M. G. 2013. The Effect of Salt Reduction on the Growth of Food Spoilage Bacteria in Model Broth Systems and Salt-Adjusted Ready Meals. Journal of Food Safety 33, 302-312. https://doi.org/10.1111/jfs.12053

FEINER, G. 2006. Meat Products Handbook. Cambridge : Woodhead Publishing, 672 p. ISBN 9781845690502

KENNEDY, C., BUCKLEY, D. J., KERRY, J. P. (2004). Display life of sheep meats retail packaged under atmospheres of various volumes and compositions. Meat Science, 68, 649-658. https://doi.org/10.1016/j.meatsci.2004.05.018

LATIFA, G. A., CHAKRABORTY, S. C., BEGÜM, M., NAHID, M. N., FARID, F. B. 2014. Nutritional quality analysis of bangladeshi fish species, M tengra (Hamilton-Buchanan, 1822) preserved with different salt curing methods in laboratory condition. American Journal of Food and Nurition 2(6), 100-107 https://doi.org/10.3329/bjz.v42i2.23369

PEREIRA, P. M., AND VICENTE, A. F. 2013. Meat nutritional composition and nutritive role in the human diet. Meat Science 93, 586-592. https://doi.org/10.1016/j.meatsci.2012.09.018.

SKOVGAARD, N. 1992. Microbiological aspects and technological need Technological needs for nitrates and nitrites. Food Additives and Contaminants 9 (5), 391-397, https://doi.org/10.1080/02652039209374089.

WOJNOWSKI, W.,MAJCHRZAK, T., DYMERSKI, T., GEBICKI, J., AND NAMIESNIK, J. 2017. Electronic noses: powerful tools in meat quality assessment. Meat $\quad$ Science, $131, \quad 131$. https://doi.org/10.1016/j.meatsci.2017.04.240

SÁNCHEZ MAINAR, M., STAVROPOULOU, D.A., LEROY, F., 2017. Exploring the metabolic potential of coagulase-negative staphylococci to improve the quality and safety of fermented meats: a review. Int. J. Food Microbiol. roč 247, 24-37. https://doi.org/10.1016/j.ijfoodmicro.2016.05.021.

SOFOS, J. N. 1984. Antimicrobial effects of sodium and other ions in foods: a review. Journal of Food Safety 6, 45-78. https://doi.org/10.1111/j.1745 4565.1984.tb00478.x

VARLIK, C., UĞUR, M., GÖKOĞLU, N., GÜN, H. (1993). Quality control methods and principles in aquaculture (174 p., No. 17). AnkaraI : Ankara Üniversitesi Ziraat Fakültesi Gıda Böl. 174 p. 